\title{
Gender, Family, and Politics of Inheritance in Pakistan
}

\author{
* Shahla Tabassum, Assistant Professor (Corresponding Author) \\ ** Dr. Amber Ferdoos, Assistant Professor \\ *** Dr. Akhlaq Ahmad, Assistant Professor
}

\begin{abstract}
There are a huge global and local gender gap in inheritance property. Men hold most material and land resources in communities and families as compared to women. Ownership of inheritance property is one indicator of the empowerment of women. This paper examines the power politics played around inheritance property within families in Pakistan. By using a qualitative interpretative feminist approach, data were collected from thirty men and women from rural and urban areas of Rawalpindi and Chakwal districts. The findings revealed that power played a very important role within the families to keep inheritance property to men. The findings further highlighted that gender ideologies are produced in the family through socialization and reproduced socially through gender stereotypes, beliefs, and social opinions to keep inheritance property within families. The researchers argue that inheritance property within the families is political that embedded power and it is ignored often when men hold power to women and children. This paper proposes to reflect upon the power of men as head of the household in the family in the context of inheritance property.
\end{abstract}

Keywords: Inheritance, Power, Politics, Family, Gender

\section{Introduction}

Gender inequality in material resources exist globally and have been highlighted in different international reports (UN-MDG, 2015; UNDP, 2015; GIESCR, 2014). International and national researchers highlighted patriarchal mindset and statuary laws based on customary practices behind this huge economic gender disparity especially in South Asian countries (Adelman \& Peterman, 2014; Berge, Daimon, Alister, \& Henrik, 2014; Brohi, 2010; SDPI, 2010; Mumtaz \& Noshirwani, 2007; Mehdi, 2002; Deere \& Leon, 2001a). South Asian societies are patriarchal and the father as head of the household played a major role in the distribution of inheritance in the family (Agarwal, 1996a). As well as most of the population live in rural areas and work in agriculture fields. Women are part and parcel of the agricultural workforce but they do not have access and control over the land resources (Velayudhan, 2014). The customary practices in south Asian countries did not allow women to cultivate the land and in case women own a piece of land, they are dependent on men for agricultural activities.

However, several researchers have found a relationship between land ownership and empowerment nationally and internationally (Kenny \& Ana Paula, 2016; Mor, 2015; Domingo, 2013; Kelker \& Maithreyi, 2013; UNESCAP, 2013; Brohi, 2010; SDPI, 2010; Mumtaz \& Noshirwani, 2007; Mehdi, 2002). Food and Agriculture Organization (FAO) (2016) also mentioned that women development and poverty reduction for women in rural areas is possible through land ownership because women put more efforts into earning for their families and communities and their landed property and inheritance rights must be protected (Women's Economic Empowerment, DAC Network on Gender Equality (GENDERNET), 2012). In African countries, women can improve their health and overcome the consequences of HIV/AIDS through ownership and control over property (Strickland, 2004), and in Asian countries, poverty in rural areas can be reduced if women have access and control over natural resources (Rao, 2005). Agarwal (1996a) highlighted women's higher economic status with women having land ownership. In this regard, women's landed property

\footnotetext{
* Department of Gender Studies, Fatima Jinnah Women University, Rawalpindi Email: shahlatabassum@fjwu.edu.pk

** Department of Sociology, International Islamic University, Islamabad Email: amber.ferdoos@iiu.edu.pk

*** Department of Sociology, International Islamic University, Islamabad Email: akhlaq.ahmad@iiu.edu.pk
} 
ownership can bring positive changes in the positions of women in family and society as well as the ideology and structure of the patriarchy (Kelker \& Maithreyi, 2013).

Article 23 of the Constitution of Pakistan (1973) granted equal rights of inheritance to women and men. The inheritance shares are distributed according to the Islamic rules which are predefined in the Quran (Engineer, 1994). Chapter 4 of the Holy Quran 'The Women' Verses 11, 12, and 176 explains the shares of an inheritance among the heirs in detail. Whatever the share of women has in the inheritance property but still, they are denied their due share in Pakistan. The purpose of the study is to explore gender inequality within the families and power dynamics which played a role while distributing and transferring inheritance property in Pakistan besides their granted religious and legal rights.

\section{Literature Review}

Global Initiative for Economic, Social and Cultural Rights (GIESCR) (2014) highlighted gender discrimination in natural resources, landed property, and inheritance across cultures as a consistent pattern as well as gender inequality in economic resources, access to and control over the landed property in its report. United Nations - Millennium Development Goals (UN- MDG) (2015) specified that natural resources and management of agriculture are male-dominated and gender blind in most of the developing countries of South Asia and Africa.

Another report of UNDP (2015) referred to the global Entrepreneurship and development Index that also emphasized restrictions in terms of legal provisions and discriminatory practices that do not allow women to get benefit from inheritance property. Adelman and Peterman (2014) argued that gender inequality in the context of inheritance is patriarchal and statutory laws are based on customary practices of the cultural system. Several types of research highlighted that women's property rights are mediated through male linage in most South Asian countries (Bibi \& Bangash, 2018; Rubab, Parveen \& Usman, 2016; Berge et al., 2014).

Deere and Leon (2001a) in their study mentioned that most of the Latin American countries are also gender-biased and preferred men for inheritance over women. They highlighted that daughters only get an inheritance if there is no male child in the family. Although some South American societies like Peru, Bolivia, and Ecuador are following a bilateral system where one can get an inheritance from both parents. In Chile, women can get an inheritance from both parents but preference is always given to sons (USAID, 2006).

Gender discrimination exists regarding inheritance property in many African countries like Kenya, Uganda, Burkina, and Tanzania. Women do not get their inheritance share because they only get benefits from the property through marriage and can get ownership with the permission of men because they are the breadwinners (kevane \& Gray, 2008). In reality, the property is registered only in the name of husbands, and in case of divorce and death of the husband, women lose that property (Kenny \& Ana, 2016).

In Tanzania, men get a greater share of inheritance than women (MOR, 2015). In Kenya, family continuation runs through male lineage so land is kept within men in the family (Harrington \& Chopra, 2010). Moreover, formal Kenyan laws carry ambiguity that creates difficulty for women to claim their inheritance share (Harrington, 2008). Although statutory and customary laws regulate inheritance property the widows are denied their inheritance share (Cooper, 2011). If any dispute occurs on inheritance, Malawi women cannot claim it through legal means, these are decided according to the customary laws as well as widows are excluded from inheritance (Own, 1996).

Rao (2005) mentioned the significance of land resources in terms of identity, status, and hierarchies within the socio-cultural context. Unmarried daughters in Nepal granted equal rights in inheritance property but it was not implemented in reality (UNWOMEN, 2014). In general, women work in agricultural fields but they are considered minors while in Sri-Lanka women have inheritance rights but often they are given poor quality land for agriculture (Velayudhan, 2014). In Bhutan, women did not own land because men are owners of land in the family (UNESCAP, 2013).

Female landownership in Pakistan is less than 3\% (HRCP, 2008) while in Punjab province, female landownership is $10.6 \%$ reported in a report of Punjab Commission on Status of Women (Shafqit \& Zahir, 2016). The studies in Pakistan focused on obstacles from cultural aspects of female landed property and inheritance. A relationship between women property ownership and avoiding taxes, women's withdraw their share and lack in handling property matters, relying on parental family, another study on women's more control on dowry than land, women's lack of awareness and 
land buying/ selling through male members and denying women's share and keeping property through illegal means were found as well as a positive relation of property and empowerment was also found Bib \& Bangash, 2018; Rubab, Parveen \& Usman, 2016; Brohi, 2010; SDPI, 2010; Mumtaz \& Noshirwani, 2007; Mehdi, 2002; Tirmazi, 1999; Arif \& Ali, 1998).

In different states of India, a strong patriarchal mindset regarding inheritance property exist and social biases excluded women from inheritance and Gujarati women justified existing practices (Dave, 2013). All the decisions are made by men regarding property matters in Nagaland reported by (Dzyyuchu, 2013). A study on widows about inheritance conducted by Kelker and Maithreyi (2013) mentioned that women are treated like witches traditionally and they cannot own the land of brothers and husbands.

\section{Theoretical Framework}

A systematic review of all above-mentioned researches conducted nationally and internationally showed institutionalized discrimination against women in the context of inheritance property highlighted largely. This has also been discussed by Radical, Marxist, and Socialist feminists and explained different reasons for the denial of women's share from inheritance property. Marxist Feminists see it as a reflection of the historical subordinate economic position of women. Collins (1993) identified domestic division of labor as the root cause of women's subordination and Eisenstein (1979) argued that women's economic inequality is based on women's unpaid work and child-rearing responsibilities which is justified through the ideology of male supremacy in capitalist societies. A shift in the family as the legal male head of the household in an independent unit of the house was seen during modern capitalism where women became dependent on their husbands, fathers, and husbands (Lee, 2010). A separation from the household to the workplace, the consequences were seen that women assigned domestic roles and men assumed public roles. Collins (1975) moves one step further and highlights men's role as head of the household through legitimate power, controlling the members of the families. She further highlighted a link between gender inequality and the political structure of the state by distinguished the legitimate decision-making power of men as head of household and state politics and a way of controlling women through marriage practices where men made decisions of marriages to control over material resources and inheritance is bargain through these marriage practices.

The book 'The Future of Marriage' by Bernard (1982) discussed inequalities in a marriage where she sees marriage as a cultural system of beliefs and institutional arrangements of roles and not a contract between two adult individuals. She argued that institutionally marriage empowers the role of husband and freedom to move beyond the domestic activities while for wives, to be dependent, self-empty, and full of domestic activities. She further claimed that culturally, for women, marriage is a source of fulfillment while for men, it is a mix of blessings. Inheritance within the families is not just a transfer of assets but a politics of family through creating and justifying these gender differences which carry on in public life and benefit men and exploit women. Moreover, Blumberg (2004) highlighted inequalities based on power which are not only economic but also political and ideological. These cultural and ideological definitions of masculinity and femininity are basic parts of the system of gender inequality which started from the family. This is also discussed by Okin (1989b) by evaluating family and market life and pointed out politics within the family where gender is a major influential factor in creating inequalities and oppression in the family. She argued that family is the first place to create this inequality by establishing relations through gender structured marriages and organized a way to control material and social resources. 


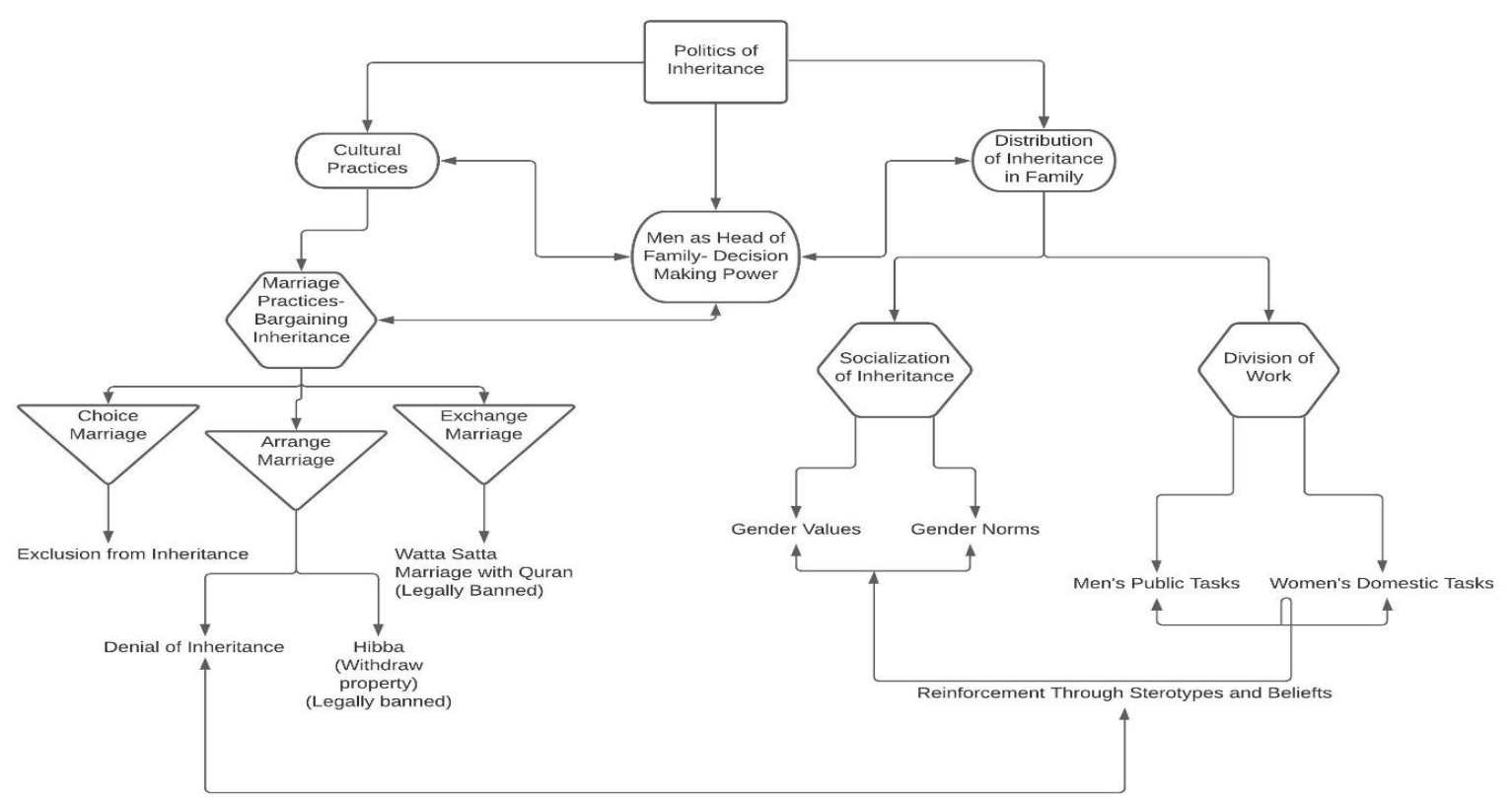

The study established links between different feminist concepts and practices of inheritance. The central idea of politics of inheritance is based on personal is political in the broader context of power relations. The politics of inheritance started through gender division of work in the family where domestic tasks are assigned to women and bread earning tasks to men. Inheritance property has an economic basis that has firm roots in the family and put women economically dependent on men through these gender division tasks. The politics of inheritance is maintained through cultural practices and men in the family as head of the household exercise this power via marriage practices which are also linked with different arrangements of inheritance property. Socializing gender norms and values to the children within the family is an indirect way of maintaining inheritance politics and exercising power to make decisions on behalf of women and children in all family matters including inheritance property. Politically, it is structured on state apparatuses where all public offices related to the transfer of property are maintained through masculine ideologies and women are unable to handle these matters in public. Although the state made legislation in favor of women regarding inheritance it goes wasted when the state declared men as head of the household and put women at the mercy of men. Below is the framework of politics of inheritance in Pakistan:-

\section{Research Methodology}

By using a feminist constructionist epistemology, a qualitative research approach was selected to get the answer to the research questions. Bernard (1994) mentioned semi-structured exploratory interviews as conversational and best suited in getting detailed and thorough information on particular topics of sensitive where researchers have only one chance of interviewing and it was reason to choose this as a method of data collection to explore the ideologies working behind inheritance distribution and transfer in the family. A purposive sampling technique was employed and the criteria were used to select the participants. 30 participants (9 rural and 6 urban women and 8 rural and 7 urban men) were selected from Rawalpindi and Chakwal areas. Key informants were used to identifying the participants on the prescribed criteria. An interview guide included a demographic, legal, opinion, and experience-based questions that were developed and used in this study.

The data was analyzed following Bran and Clarke's (2006) six steps of thematic analysis. The first step is the stage of familiarizing and understanding the data and in this stage, all the recorded interviews were transcribed and started developing initial codes. The second step included assigning numbers to the initial codes from the first transcribed interview and looking at how many times one code is repeating in the coming interviews that give an understanding of the patterns as well. In the third stage, all those codes were put under different concepts used in the theoretical frame. The next and fourth step included putting these concepts into different categories with a feminist lens used in this study. Step five included theoretical categories into different themes. In the last step, all these themes were reported under the results part. 
In qualitative research, objectivity and truthfulness about findings of the research is an important aspect, and to maintain it, criteria developed by Guba and Lincoln (1994) was used to evaluate the objectivity and trustworthiness of the findings.

Ethics play a very important role in qualitative research and to maintain ethical standards in this study, participants were informed about the purpose of the study and got permission to record their interviews. Places of interviews were selected according to their convenience and they were assured about the confidentiality of the information. In this study, it was maintained by using numbers instead of their names during the analysis and reporting period.

\section{Results and Discussion}

The findings highlight the politics of family played around inheritance which is constructed through gender ideologies. The power within the family is the key element of the politics of inheritance which is often ignored but it became obvious through distribution and transfer of inheritance property. The information collected from the participants are presented below in different themes as follows:

\section{Hidden Politics of Inheritance}

Hanisch (1969) used the term 'Personal is political' first time and later used by second-wave feminism in a broader context of power relations and mentioned women's problems as political. The findings highlighted meanings of inheritance in a legal, religious, and cultural context shared by the male participants only. Some of the dominant definitions of inheritance explained by eight rural male participants in a cultural context as

"Elder son is the owner of the property in the family after the death of the father" (Rural Male 2,55 years)

"Inheritance is all about the property of the father" (Rural Male 7, 58 years)

Additionally, four urban male participants defined it religiously and said that in Islam

"Parents' property is the right of the children and one part goes to son and half to the daughter" (Urban Male 7, 26 years)

"Father has the right to give his property to a specific child in his life but after death, it is divided equally" (Urban Male 1, 60 years)

No women defined inheritance and only men defined inheritance in the context of law, culture, and religion but they only defined distribution of property among the heirs and did not discuss the transfer aspect of property as inheritance completed when it is transferred to the concerned parties. These several meanings not only produce misunderstandings for women to recognize the true meaning of inheritance but also limits the distribution of inheritance property among the heirs. My argument here is that creating ambiguity on the meaning of inheritance is deliberate because it becomes difficult for people to understand and women who are already not trained about property matters could not understand inheritance and believe that men know property matters well. Creating ambiguity around the meaning of inheritance is a way of controlling women's property and maintaining power within the families.

\section{Politics of Inheritance: Gendered Structured Marriages}

West and Zimmerman (2005) discussed a link between gender ideologies and power that is used to control subordinates by establishing a politics of differences where differences become an instrument to justify exploitation. The findings revealed marriage implications for women about inheritance property. Six rural and one urban female while six urban and one rural male participants mentioned that to marry and have children is all for in women's life as well as women always showed lack interest in property-related matters.

"Women thanked Allah that they have all facilities at home and they do not need anything and no interest in getting property from family" (Rural Female 7, 62 years)

"She did not need to know about inheritance matters as she is married now and have everything at home" (Rural Female 5,42 years)

Bernard (1982) argued that marriages are gendered practices that not only benefit men but also women. Male participants mentioned that the daughters are trained in a way to think that they should get a good education so their parents could marry them with good families. U M 4 said that

"Marriage is the only important aspect of women's lives and they only think about marriage and children in their lives" (Urban Male 4, 32 years)

In Pakistan, it is considered the parent's responsibility to marry their daughters by arranging marriages within equivalent families of status. 
"It is the responsibility of parents to marry their daughters and when the daughters are married, then they do not need to give property as they have moved to another house" (Urban Male 1, 60 years)

"Parents want to see a secure future of their daughters and tried to select a well-settled family where inheritance property is no more important to them" (Rural Female 2, 30 years)

In these areas, cousin marriages are also popular as Rural Female 8 and 9 highlighted cousin marriages as a popular way of keeping inheritance within the family in their areas.

"Parents prefer to marry their daughters within the family to keep inheritance property, if they did not find any good one then they look outside the family for their marriage" (Rural Male 3, 48 years) While

"Most of the time marriages consciously arranged because of keeping the property within men of the natal family" (Urban Female 6, 42 years)

Here the argument is that marriages are not relationships between two adult individuals in Pakistan but are political and used in favor of men just to control material resources. Making decisions of adult marriages by the parents rather than two independent individuals is another way of bargain property with the other head of the family. Inheritance is political that works through ideologies of differences and creates inequality that both men and women see inheritance through an existing gender lens and support distribution of material resources and family responsibilities according to the cultural context. Women are unable to understand the lack of agency in their marriages and the implications of marriage that kept them economically dependent on men in general and specifically in distributing inheritance property. Okin (1989) highlighted family as the root of creating inequality through gender structured marriages and a means to control social and material resources in the family.

\section{Politics of Inheritance: Production of Gender Ideologies in Family}

The family is considered as natural and a place where everyone's interests are protected. Okin (1989) challenged family as natural because developing different identities and adopting different roles in the family based on gender is apolitical. The findings revealed that family is the first place of socialization and the process of internationalization of inheritance is gendered. Men are trained about land, crops, and as breadwinners of the family, and women are trained to take care of the family and depend on men for economic gains.

"Information related to inheritance is only shared with men and women are not considered part of the house. (Rural Female 8, 40 years)

"These are the mothers who train their daughters that certain things belong to their brothers and they are supposed to comply with their brothers so they are socialized of sacrificing in favor of their brothers"(Urban Male1, years)

"Women are socialized in a way that they do not think about inheritance property and even they have not seen their sisters and mothers for asking their inheritance so they never imagine asking for their inheritance property"(Rural Female 3,38 years)

Despite socialization, the main source of women's exploitation of inheritance is their dependence on men. This dependence stems from many things such as lack of awareness, knowledge, money, time, and restricted mobility in the family. This is also reflected in the information provided by participants as U M 2 said that

"Women are not provided inheritance information even after the death of their parents and they are just asked to sign the papers" (Urban Male 2, 62 years)

"Women are not trained to move independently alone in public life and they faced a hard time if they want to get their inheritance share" (Urban Female 1, 48 years)

"Women in our society are too busy in domestic tasks and did not have time to get knowledge about the inheritance procedures and laws" (Rural Female 3, 38 years)

"I have been teaching in a government school for the last 28 years and living in this house for the last 21 years but I do not know about my neighborhood as I am not allowed by my husband to meet with people. Even I did not try to make friends just to avoid a dispute with my husband" (Urban Female 1, 48 years)

Moreover, women could not get inheritance due to lack of time and money as they are busy with their domestic tasks. (Rural Female 9, 28 years) 
"Women only ask for inheritance when they need the money and going to court demand time and money both which women do not have and they are dependent on men economically and busy in domestic tasks" (Urban Female 4, 55 years)

The argument here is that family is political as the power within the families is not recognized whether it is husband power over women or parent's power over children. Socialization of gender division of labor within families have implications on women in public life because of their male dependency and getting their share and transferred property comes under public domain, requiring time, money and knowledge, which women lack, hence a cause of exploitation. This is also supported by Okin's (1989) argument that gender division of labor within families creates obstacles for women's life and they are unable to cope with later in public life.

\section{Politics of Inheritance: Social Reproduction of Gender Ideologies}

Gender ideologies are reinforced through stereotypes and prevailing beliefs related to inheritance property. The findings highlighted the important stereotypes and beliefs that maintain gender ideology and promote land ownership about men and exclude women to maintain inheritance property in the family. These narratives are reflected by the participants as:-

"Men love the idea of land as it can be seen by their admiration of word 'Rajput' which means 'son of the land"' (Rural Male 8, 77 years)

"Land is a show of power and honor to the family in a rural setting so that's why parents do not distribute land among the daughters" (Rural Female 6, 34 years)

"Men are responsible to handle property matters including documentations of the land as women cannot understand these documents" (Urban Female 2, 50 years)

Beliefs surrounding inheritance are also gendered and operate like a system that builds on the norms systematically prevailing in society. Gendered beliefs also play a role to create a hurdle for women to get the inheritance.

"Women do not have an inheritance because of their mindset as they believe that asking for inheritance means that they do not care about the family"(Rural Female 1,38 years)

"It is men's thinking that women are provided food, clothes, and shelter and they do not need to give inheritance property"(Urban Female 3, 50 years)

"It is the non-willingness of brothers to give sisters inheritance share, coming from their thinking towards women's inheritance share" (Urban Male 1, 60 years)

"Fathers do not consider giving their daughter inheritance share" (Rural Male 3, 48 years)

Further, findings also highlighted the prevailing beliefs in society that force women to leave their share.

"Men by birth are entitled to land" (Rural Female 6, 34 years)

"Men are the Head of Household' and the 'Relationship are more important than property"

(Rural Female 9, 28 years)

The opinion that people hold in society to keep women away from inheritance by stigmatizing women on demand for inheritance. She is considered a good woman if she complies with prevailing norms of society and if does not then label as bad. These are supported by narratives of participants as:-

"It is difficult for women to go court and get their inheritance share, they have to listen to the bad comments passed on them" (Urban Female 2, 50 years)

"The women who took their inheritance share through court, they are labeled as bad sisters and I am a bad sister because I have taken my share from the court" (Rural Female 6, 34 years)

Urban Male 5, Urban Female 2, 4, 6 mentioned that going to court for women is considered a bad thing and people talk bad remarks on women while Rural Male 6 said that there are very few women who go to court. Rural Female 1 stated that women never dare to go to court in her area. Rural Female 2 said that visiting court means losing the self-respect of a woman in society

"The family start spreading comments as a rebellious one who is demanding her inheritance share and it happened with me when I asked for my share"( Rural Female 1, 38 years)

Urban Female 3 shared that her sister in law said to her that

"She has withdrawn her inheritance in favor of her brothers so she should act accordingly.

(Urban Female 3, 50 years) 
"If a woman is working for a paid job, her family expect her to withdraw her share as she has enough money and her husband forced to demand her share. I do not want to lose my family support as I am not aware of time to get support from them" (Rural Female 1, 38 years).

These stereotypes, beliefs, opinions may not directly stop women from getting their rights but they do influence the actions of people around them. The argument here is, this is political as these are consciously spread and used in times of need to stop women from demanding their right to inheritance. Besides this, an assigned role of men as head of the household to make decisions on behalf of the family confirms all these beliefs. These are supported by De Beauvoir's (1949) idea of the social construction of women as a deliberate assertion of the power of men to retain women subordinate. She argued that women are kept in this situation purposely where they adopt domestic roles which are reinforced through social reproduction of gender stereotypes, beliefs, and opinions.

\section{Conclusion}

The politics of inheritance started from the family that holds power within men and create inequality from the beginning of a person in society. Inheritance is the outcome of what both men and women have socialized in their life as a gender person, not the beginning of the distribution of material resources among the family members. The formation of relations between men and women through marriage is the determining factor which is based on power and are produced and reproduced injustices and inequalities in the family based on material resources. Denying women's inheritance rights is the outcome of inequality started in the family through early childhood socialization and spread to all phases of life. These inequalities are reinforced through using different techniques such as stereotypes, opinions, and beliefs which are not only difficult to understand in the context of inheritance but also to get rid of them. All the efforts to achieve equality and empowering women go wasted when the state guarantees men the right to head of household as women lose opportunities and are unable to move into public offices. It is important to understand women's subordination and dependency in the wider social, political and cultural context as inheritance is legally and religiously granted in Pakistan but inheritance denial started in the family to keep women economically dependent.

\section{References}

Ahmad, N. (2010). Land Rights for Muslim Women: Review of Law and Policy. Accessed online www.sdpi.org/publications/files/Microsoft\%20word\%20\%20policy\%20Brief\%2013.pdf.

Arif, K., \& Ali, S.S. (1998). The Law of Inheritance and Reported Cases Relating to Women in Farida Shaheed (Eds.), Shaping Women's Lives. 163-168. Lahore: Shirkat Gah

Berge, E., Daimon, K., Alister, M. \& Henrik, W. H. (2014). Lineage and land reforms in Malawi: Do matrilineal and patrilineal landholding systems represent a problem for land reforms in Malawi? Land Use Policy. Retrieved from www.sciencedirect.com/science/article/pii/ S0264837714000945 Accessed on 10th July 2017.

Bernard, H. R. (1994). Research Methods in Anthropology: Qualitative and Quantitative Approaches. London: Sage Publications.

Bernard, J. (1982). The Future of Marriage. Yale: Yale University Press.

Bibi, F. \& Bangash, K.A. (2018). DENIAL OF WOMEN'S INHERITANCE RIGHTS IN PAKHTUN SOCIETY: A STUDY OF SOCIO-CULTURAL VALUES AND CUSTOMARY PRACTICES. Pakistan Journal of Society, Education, and Language (PJSEL), 4(2), 40-53. Retrieved from https://pjsel.jehanf.com/index.php/journal/article/view/97

Blumberg, R. L. (2004). Women's Rights, Land Rights, and Human Rights: Dilemmas in East Africa. Journal of Development Alternatives and Area Studies, 23(3-4), 17-32.

Bran, V. \& Clarke, V. (2006). Using Thematic Analysis in Psychology. Qualitative Research in Psychology, 3(2). 77-101. Taylor \& Francis Group.

Brohi, N. (2010). Gender and Land Reforms in Pakistan. Policy paper series \# 34 SDPI. Islamabad: Sustainable Development Policy Institute

Collins, R. (1975). Critical Sociology: Towards an Explanatory Science. New York: Academic Press.

Collins, R. (1993). Emotional Energy is the Common Denominator of Rational Action. Rational and Society, 5(2). 203-230. Retrieved from https://journals.sagepub.com/doi/10.1177/104346 $3193005002005 \mathrm{pdf}$

De Beauvoir, S. (1988). The Second Sex. First Published in 1949. London: Jonathan Cape. 
Domingo, P. (2013). Property Rights and Development: Property Rights and Social, Political, and Economic Empowerment. Shaping Policy for Development. London: Overseas Development Institute. Retrieved from https://www.odi.org/sites/odi.org.uk/files/odiassets/publications. ..files/8508.pdf

Eisenstein, Z. (1979). Developing a Theory of Capitalist Patriarchy and Socialist Feminism. Capitalist Patriarchy and the Case for Socialist Feminism, 5-40.

Engineer, A. A. (1994). Muslim Family Law. In Sarkar, Lotika, and Sivaramayya (Eds.), Women and Law Contemporary Problems. New Delhi: Vikas Publishing House Pvt. Ltd.

Food and Agriculture Organization (2016). Gender and Land Rights-Understanding Complexities, Adjusting Policies. Retrieved from www.fao.org/gender/landrights. Accessed on April 24, 2018.

GENDERNET. (2012). Women's Economic Empowerment, The OECD DAC Network on Gender Equality (GENDERNET), Promoting Pro-poor Growth: The Role of Empowerment-OECD 2012. Retrieved from www.oced.org/dac/poverstyreduction/50157530.pdf. Accessed on July $14,2018$.

GIESCR (2014). The Global Initiative for Economic, Social and Cultural Rights. Using CEDAW to Secure Women's Land and Property Rights: A Practical Guide. Retrieved from www.globalinitiativeescr.org/wpcontent/uploads/2014/03/CEDAW-Guide.pdf. Accessed on May 6, 2018.

Hanisch, C. (1969). The personal is Political. Introduction by Carole Hanisch, 2006.

Judoon, M.A. \& Khan, R. (2015). A Survey of Practices and Methods of Denial of Inheritance to Females in Khyber Pakhtunkhwa, Pakistan. Pakistan Journal of Criminology, 7(4), 112-126.

Kelker, G. \& Maithreyi, K. (2013). Women, Land \& Power in Asia. New Delhi: Routledge.

Kenney, N. \& Ana, P. (2016). Developing Gender-Equitable Legal Frameworks for Land Tenure: A Legal Assessment Tool. Rome: Food and Agriculture Organization of the United Nations.

Lee, Yoke-L. (2010). A-Z Glossary. In Lee, Yoke-Lian (Eds.), The Politics of Gender a Survey (177342). United Kingdom: Taylor \& Francis.

Mehdi, R. (2002). Gender and Property Law in Pakistan: Vanguard Publishers.

Mumtaz, K. \& Noshirwani, M. (2007). Women's Access and Rights to Land and Property in Pakistan. Scoping Study. International Development Research Center (IDRC).

National Commission on the Status of Women in Pakistan, (2008). Women's Rights of Inherence and its Implementation. Islamabad: Government of Pakistan.

Okin, M. S. (1989b). Justice, Gender, and the Family. United State of America: Basic Books.

Rawls, J. (1971). A Theory of Justice. Cambridge Mass: Harvard University Press.

Rehman, U. S. (2010). Denial of women's Rights of Inheritance: Enhancing their Vulnerability to Domestic \& Social Violence. Awaz Foundation Pakistan: Centre for Development Services Multan, Pakistan.

Rubab, I., Parveen, S. \& Usman, A. (2016). Islamic Law of Inheritance: Awareness among Women of Punjab. Al-Qalam. 21, 11-23.

SDPI (2008). Land rights for Muslim women: Law and Policy Review. Islamabad: Sustainable Development Policy Institute.

Shafqat, A., \& Zahir, H. (2016). Evaluating 2015 Legal Reforms Related to Land Inheritance and their Impact on Women. Lahore: Punjab Commission on the Status of Women.

UN Economic and Social Commission for Asia and the Pacific (UNESCAP) (2013). Review of the Progress and remaining challenges in the implementation of the Beijing Platform for Action in Asia and the Pacific. Asian and Pacific Conference on Gender Equality and Women's empowering: Beijing +20 review. Bangkok.

UNDP. (2015). Human Development Report 2015: Work for Human Development. New York: United Nations for Development Program.

UN-MDGs. (2015). The Millennium Development Goals Report 2015. New York: United Nations.

USAID. (2006). Study on Women and Property Rights: Project best Practices. United States Agency for International Development. Retrieved from www.pdf.usaid.gov>pdf_doc>Pnadj420. Accessed on April 26, 2017. 
USAID. (2013). Land Rights are Fundamental to Millennium Development Goals. Retrieved from www.usaidlandtenure.net/.../land-rights-are-fundamental-to-millennium-development. Accessed on May 12, 2018.

West, C., \& Zimmerman, D. (2009). Accounting For Doing Gender. Gender and Society, 23(1), $112-$ 122. Retrieved August 25, 2020, from http://www.jstor.org/stable/20676758

Zaman, S. (2014). Forced Marriages and Inheritance Deprivation in Pakistan: A Research Study Exploring Substantive and Structural Gaps in the Implementation of Prevention of AntiWomen Practices [Criminal Law Amendment Act], 2011 in Six Select Districts of Pakistan. Lahore: Aurat Publication and Information Service Foundation. 